\title{
A sense of entitlement? Fathers, mothers and organizational support for family and career
}

\begin{abstract}
The influential work of Suzan Lewis has played an important part in shaping understandings of parenting, work-life integration and gendered values and practices in organizations.
\end{abstract}

Below, we offer a brief outline of how Suzan's work has influenced the work-life research field. We focus particularly on her observations about career advancement, gender and a sense of entitlement (or otherwise) among employed fathers and mothers.

In particular, we build on Lewis’s (1997) notion of 'entitlement' among and between employed parents regarding access to family friendly and/or flexible working and personal career advancement. We extend Lewis’s ideas through developing a framework which reflects the relative sense of entitlement (or lack thereof) between fathers and mothers in relation, respectively, to 'support for family needs' and 'equity in career development' (1997:15). We then advance and update this framework through suggesting that a sense of entitlement among today’s fathers, regarding access to family friendly working, may be undergoing a social shift.

Drawing upon Lewis's important contribution to the work-life field, the paper thus explores how understandings of fatherhood are changing. We then consider what future research agendas might be.

\section{Introduction: Suzan Lewis’s contribution}

We are delighted to celebrate Suzan Lewis’ contribution to the field of work, family and organisations through this Special Issue, celebrating 30 years of Suzan’s work. Cary’s association with Suzan stretches back over many years not only as long-standing colleague 
and friend, but also as Suzan's doctoral supervisor. Caroline met Suzan in 2005 as part of a working group producing a special issue on 'Work-life Balance' for the International Journal of Human Resource Management, in which Suzan’s influential (and now highly cited) 2007 paper (with Gambles and Rapoport) was published. Not only do we both value Suzan’s longstanding friendship and support but we also value her important contribution as a colleague who has consistently been at the leading edge of the work-life field.

In this paper, we reflect on Suzan's valuable influence within the fields of work, family and organizations. Her work is important because she was one of the first scholars to contextualise her work-family research across disciplinary boundaries (see Lewis and Cooper, 1999), making connections between the often distinct areas of management, psychology and sociology.

Over the past three decades, research on 'work-life integration' (Lewis and Cooper, 2005) has proliferated. We note how Suzan's work has highlighted the gendered nature of work-life discourse and policy, and we observe how her work has influenced the field in relation to identifying gendered values and practices. We pay particular regard to her identification of fathers as an under-represented group with a low sense of entitlement to work-family support.

Specifically, we build on Lewis’s (1997: 15) notion of 'entitlement' through developing a framework which reflects the relative sense of entitlement (or lack thereof) among fathers and mothers regarding both 'support for family needs' and 'equity in career development'. We observe changes in beliefs among contemporary fathers regarding paternal entitlements to access work-family initiatives. We then extend and update this framework through suggesting that men's sense of entitlement, regarding access to family friendly working, may be changing. Having made our points about the sense of entitlement to career advancement 
and family support among fathers and mothers respectively, we reflect upon how things have changed and make recommendations for a future research agenda.

We begin with a brief outline of how the work-life balance research field has addressed the complex issue of combining parenthood with employment, then we consider notions of parenting, entitlement and gender.

\section{The work-family research field}

Since the late 1990's, Lewis and her co-authors have made significant contributions to the identification of gender as a deeply ingrained, often troubling theme within work-life balance literatures, perhaps especially with regard to fathers. The call from Lewis et al. (2007) to broaden the work-life research agenda, extending this beyond dual earner couples in AngloAmerican settings, is shown to have sparked debate and enriched the work-life research agenda (see for example, Fleetwood, 2007).

As observed by Lewis et al., (2007) late twentieth century 'dilemmas' experienced by parents managing the complexities of work-life integration produced a surge in research on work, family and organizations. This surge flourished within the disciplines of organisational psychology (Pleck 1977, Parasuraman et al., 1989), management studies (Kanter, 1976; Özbilgin et al., 2011) and sociology (Rapoport and Rapoport 1965; Hochschild, 1997). (We note, here, how Lewis's work enhanced the trajectory within work-life research through drawing together observations which had previously been made within disciplinary 'silos', thereby creating a broader platform for debate). This growing interest in work-life issues among and between research disciplines has been attributed by Lewis et al. (2007) and Lewis and Cooper (1999), to two social concerns. The first of these two concerns relates to women's increased presence within labour markets, and the impact of women's changing work patterns on family practices (Crompton, 1997; Estes, 2004; Greenhaus and Beutell, 
1985, Greenhaus et al., 1999; Swan and Cooper 2005; Lewis et al., 2007). The second - and more recent - social issue relates to the changing nature of employment practices. Recession during the 1990's has prompted shifts in working practices, leading to a reduction in secure, permanent forms of employment and an increase in market-dependent jobs with short-term contracts (even among high level roles). Such job insecurities may be seen to have heightened work-load intensification, as workers feel under pressure to appear visible and hard-working within their organizational settings (Collinson and Collinson, 2004; Lewis and Cooper, 1999). Resultantly, management positions have tended to be characterised increasingly by long hours and a requirement for employees to be available to organizations during evenings and weekends, even if this is not part of their contract (Lewis and Cooper 2005). Lewis et al., (2007) attribute to neo-liberal economies this predominance of longhours cultures, neo-liberalism privileging 'competitiveness through minimal regulation and reliance on market forces' meaning that the 'imbalance between paid work and the rest of life’ has become increasingly acute (Lewis et al., 2007: 361, see also Worrall and Cooper, 1999).

Fathers appear to be most closely affected by intensified workplace cultures, as men with infant children are shown in particular to work longer hours than at any other point in their careers: 'While marriage and fatherhood may be linked to career development, career success means more demanding work and longer hours; that is, more time spent away from the family’ (Halford, 2006: 386, see also Crouter et al., 2001; Hochschild, 1997).

Yet despite these apparent pressures on men with families to work more intensively and for longer hours, fathers are shown often to fade into the background within the context of worklife research and policy. Since the 1970's, work life balance research in the arenas of 
sociology, organizational psychology and management has focused primarily on the worklife balance of mothers within heterosexual (and often, by implication, affluent) dual earner couples (Lewis and Cooper, 2005; Ozbilgin et al., 2011). Notably, such a focus on work-rich couple earners has been criticised by scholars examining the position of service workers on low wages and with poor working conditions (see for example, Collins, 2007).

Albeit with exceptions (for example Gershuny et al., 1994; Gershuny, 1997; Brandth and Kvande, 2001; Featherstone, 2009; Gatrell 2005; Halford, 2006) fathers have tended (especially prior to 2000) to be omitted from policy debate (Burnett et al., 2010). This omission is due to long standing organizational perceptions that mothers are primary parents, while fathers are usually main income earners within households (Delphy and Leonard, 1992; Greenhaus and Beutell, 1985; Maushart, 2002; Tomlinson, 2007; Tracy and Rivera, 2010).

Such emphasis on motherhood is unsurprising, given that research demonstrates how women continue, unfairly, to carry the main burden of what Burnett et al., (2010) term the 'domestic care agenda’ (Delphy and Leonard 1992; Maushart 2002), and earn consistently less than men with equivalent qualifications/jobs (Thompson et al., 1999, Blau et al., 2014, Padavic and Reskin, 2002). This consistent research finding has encouraged organizations to develop enhanced work-life balance policies and flexible working options with mothers in mind (Greenhaus and Beutell, 1985, Lewis and Cooper 1999; 2005). Work-life literatures, especially those written from a feminist perspective, have thus focused on gender equity, promoting mothers' right to remain in the labour market following childbirth and arguing that domestic and childcare labour should be shared more equally between mothers and fathers (Davidson and Cooper, 1992; Oakley, 1981; Rich, 1977; Maushart, 2001). Research findings showing how mothers are consistently disadvantaged within labour markets due to their actual or potential child care responsibilities (Blair Loy, 2003) have thus encouraged 
organizations to develop enhanced work-life balance policies and flexible working options with mothers in mind (Lewis and Cooper 1999; 2005; Özbilgin et al., 2011).

Yet while work-family initiatives are shown in some respects to have enhanced maternal working conditions (Lewis and Cooper, 1999), the location of work-life balance policies within a maternal context may also have produced some unanticipated and undesirable sideeffects for mothers (and, arguably, also for fathers). It has been suggested that the work-life research and policy focus on mothers has further contributed to the shaping and perpetuating of employers' (often inaccurate and out-dated) assumptions that parents are usually in heterosexual relationships and that domestic care responsibilities are allocated along traditional gendered lines (Tracy and Rivera 2010; see also Blair Loy, 2003). Organizational presuppositions that mothers' careers are likely to be afforded predominantly secondary status within households could be said to have become a self-fulfilling prophecy. This is because mothers' greater use of flexible working opportunities (at least compared with paternal usage of such initiatives) supports and reifies the assumption, within organizations, that work-life balance policies exist principally for women and are less applicable to men (Tracy and Rivera 2010, see also Lewis and Cooper 1999; Lewis and Cooper 2005). Furthermore, mothers who are working flexibly (especially if working part-time) are often presumed within organizations to be less work-orientated than full-time workers. Mothers working part-time are consequently positioned on a career limiting 'mommy track' and are thus unfairly but effectively denied career advancement, regardless of their personal ambitions (Blair-Loy, 2003, Smithson and Stokoe, 2005).

Although contemporary work-life policies are framed, theoretically, to embrace 'parental' needs, employers' assumptions that mothers are the primary users of work-family initiatives have serious consequences for men because in practice, fathers are often excluded from 
family support offers (Burnett et. al., 2010; Tracy and Rivera, 2010). Organizational policies may be hypothetically gender neutral, designed around 'parental' needs. However, attitudes among senior staff (both male and female) with authority to implement such policies remain often suffused with gendered assumptions about maternal responsibility for domestic care agendas (Burnett et. al., 2010; Tracy and Rivera 2010). As a result, fathers continue to be discouraged from utilising family support policies, due to suppositions among both senior executives and more junior line-managers that fathers are likely to be work-oriented primary breadwinners, living with the mother of their child and neither needing nor desiring to prioritise child care alongside paid work (Tracy and Rivera 2010).

Such preclusion of men from work-family initiatives is problematic for both mothers and fathers as it fails to take account of changing family practices. The 'Parsonian’ image of heterosexual couple parenting, in which fathers are positioned as lead income earners and mothers as principal child carers (see Gatrell, 2005) may be increasingly irrelevant to men and women who are not parenting within intact heterosexual relationships. Parents may be single, divorced, living in blended families or in single sex relationships and/or seeking to allocate responsibilities for paid work and domestic care according to criteria other than gendered lines. These groups might need family support and flexibility in circumstances where men are main carers, for example in gay relationships where both parents are male, or where divorced heterosexual fathers are closely involved in child care. Furthermore, even where fathers and mothers are parenting in heterosexual couple households, there is an increasing tendency for mothers to be main breadwinners (Blau et al., 2014; Ford and Collinson, 2011). Consequently, fathers may be equally as likely as mothers to undertake child care and to require flexible working options, including in low income families (see Coltrane et al., 2004, with reference to Mexican American fathers). 
Part of the reason for lack of paternal access to flexible working is therefore structural, in that organizations may be unaware of, or unreceptive to the idea that men, as well as women, require access to work-family support and initiatives. (Such structural constraints are exacerbated because financial support for paternity leaves in the U.S.A. and U.K. is often very limited, see Blau et al., 2014; Moss, 2014; Kadar-Satat and Koslowski; Working Families, 2015) Furthermore, while maternity and work-life balance has been central to policy debate for over thirty years, research centring on paternity and employment has been less dominant, meaning that pressures to foreground fathers needs have not been as prominent (Özbilgin et al., 2011).

It is recognised that workplace assumptions about fathers being less unencumbered than mothers by childcare responsibilities offer to men a significant benefit as regards employment prospects (Höpfl and Hornby Atkinson, 2000). Regardless of whether organizational images of men as primarily work-oriented accurately reflect individual paternal practices, such images are known to advantage men in career terms (Blau et al., 2014), while association of mothers with child care responsibilities has the reverse effect (Desmarais and Alksnis, 2005). However, while organizational assumptions about fathers' limited responsibility for childcare may privilege men as regards career advancement, such views could also be seen to reproduce structural disadvantages to men in their paternal roles. As noted above, fathers are expected to demonstrate high work-orientation through compliance with long-hours cultures at work, as well as being available electronically when supposedly off duty (Dienhart, 1998; Kvande, 2005). Line-managers are often unsympathetic towards men’s requests to work flexibly and it is perhaps unsurprising therefore that employed fathers (even those who planned significant involvement with children prior to birth) have tended consistently to 'fall back’ into the gendered roles expected of them (Miller, 2011, see also Dermott, 2008). 


\section{A sense of entitlement}

Drawing up on the work of Lewis (1997), we now consider how organizational structures, which cause mothers and fathers to 'fall back' into gendered roles (Miller, 2011), have previously been mirrored in gendered beliefs among individual men and women about their respective entitlements (or otherwise) to family support and career advancement.

For example, in a study of the accounting industry (Smithson et al., 2004) it was apparent that the accounting organizations studied were relatively open to facilitating maternal employees in arranging their working hours to suit the needs of young families. However, offers of such flexibility were accompanied by line managers’ perceptions that fathers should not expect to access such facilities. The few men who did seek to organize working practices around family needs attracted criticism and opprobrium. It was also apparent within Smithson et al's study that mothers were expected to bear a cost of limited career advancement as a result of working flexibly (a finding which is in keeping with more recent observations about maternal employment by Blau et al., 2014). Perhaps unsurprisingly, in the light of these constraining and gendered organizational contexts, Lewis (1997) has observed how women tend to exhibit a 'lower sense of entitlement than men regarding levels of pay'. At the same time, however, Lewis notes how mothers feel more entitled than men to assert family needs because this is congruent with gender expectations at work (Lewis, 1997: 15).

It is suggested that men have, by contrast (at least until the turn of the $21^{\text {st }}$ century), felt more confident about their claims to career advancement and enhanced pay than about their role as parents. Consequently, while employed men have assumed career development to be their due, they appear, until recently, to have felt less entitled to ask for family support (Lewis, 
1997). Many of today's employed fathers (especially those in heterosexual couples) have thus failed to make their work family needs known at work and have 'fallen back' into gendered breadwinning roles, even if was not their intention prior to becoming parents (Miller, 2010, 2011; Dermott, 2008).

Figure 1 illustrates this contrast between maternal and paternal sense of entitlement regarding organizational support for career and family needs respectively. It shows how organizational assumptions regarding male and female roles may contribute to the stabilization of gendered practices at work.

Figure 1: Parents and entitlement to family support and career advancement

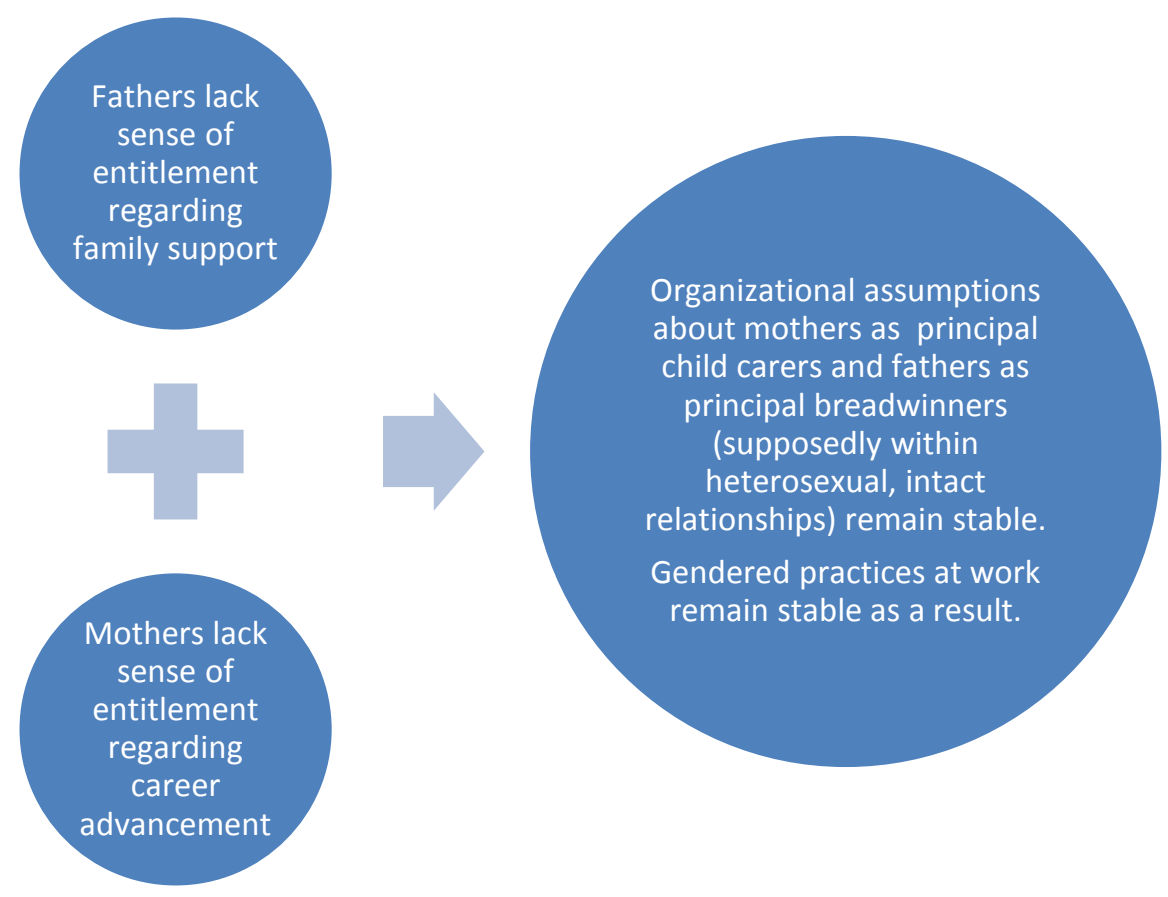

On the face of things, therefore, it might appear that despite the introduction of family support initiatives at work, the division of labour between family and income earning among mothers and fathers remains consistently gendered. Individual parents appear often to feel confined within 'Parsonian' patterns of behaviour (Gatrell, 2005) regardless of whether such 
patterns may be appropriate or desirable within individual contexts. Resultantly, scholarly concerns have expressed regarding the impact of gendered organizational assumptions about parenting on agentic capacity among fathers and mothers to interpret how responsibilities for earning and domestic care should be shared (Dermott, 2008; Eräranta and Moisander, 2011; Lewis and Cooper, 2005; Miller, 2011).

Yet arguably, while many fathers (and mothers) continue to find it hard to resist gendered organizational expectations about work and family, some research on parenting post-2000 also suggests the possibility that change is afoot. It is to these findings which we now turn as we highlight some new studies which identify a potential shift among paternal attitudes regarding entitlement to 'support for family needs' (Lewis, 1997: 15). We suggest that these changes to paternal sense of entitlement regarding family support at work could impact on the status quo as regards the gendering of work and family practices.

It is acknowledged, here, that paternal capacity to earn income so as to contribute financially to children's upbringing may remain fundamental to a sense of masculine identity among fathers (Christiansen and Palkowitz, 2001). This is the case across a range of economic situations including among young men with low incomes, who are known to interpret the provision of income as inextricably intertwined with 'good' fathering (Shirani 2015). Nevertheless, while employed fathers often continue to take a line of 'least resistance' to organizational expectations that they should 'fall back' into gendered behaviour patterns (Miller, 2011) some research post-2000 observes a difference in the sense of entitlement to family support among some employed men. Although organizational attitudes (especially among line managers) may remain embedded in assumptions about men's work orientation, it 
is arguable that a shift is occurring in attitudes (and working practices) among some employed fathers.

\section{Paternal entitlements}

As early as 1995, Beck and Beck Gernsheim predicted a change in paternal approaches to father-child relationships, especially among heterosexual men who sought to develop and maintain engaged relationships with children post-separation/divorce (see also Philip, 2013, 2014). Neale and Smart (2002); Smart and Neale (1999) and Smart et al., (2001) provided empirical evidence to support Beck and Beck Gernsheim’s (1995) theory about divorced fathers' enhanced family orientation. They showed how, although some separated/divorced fathers retained limited contact with families, other men were determined to share in the day to day lives and care of dependent children (though not necessarily the household chores that might accompany such care, see Neale and Smart, 2002). These observations began to raise the prospect that, contrary to workplace expectations, divorced and separated fathers might both desire, and need, to work flexibly in order to care for their children, at least during the parts of the working week when they were acting as lead carers, even if they were not 'resident' parents (see also Doucet, 2006).

Until 2000, it was usually assumed that married or co-habiting fathers within intact relationships were content to leave to mothers the responsibility for mediating paternal-child relationships on their behalf (Ribbens, 1994). At the turn of the century, however, new research began to identify a marked change in attitude among some married/co-habiting men. As noted earlier, Dermott (2008) and Miller (2011) both identified a desire among new fathers (within heterosexual couples) to be involved directly with children’s upbringing, even if such desires were constrained in practice by organizational expectations about paternity 
and breadwinner roles (see also Eräranta and Moisander, 2011; Gatrell, 2005, 2007; Holter, 2007).

Perhaps unsurprisingly, in circumstances where paternal desire for (or need of) family support is increasing but is unmet, some men are beginning to question lack of paternal entitlements at work. Such questioning may be particularly acute in circumstances where family support is supposed to be on offer to 'parents', but where line-managers have not anticipated that fathers would require, or wish, to access such opportunities (Working Families, 2011). In cases where men are working for organizations which are perceived to privilege maternal entitlement, this causes resentment. Men are not used to feeling second best when it comes to workplace privileges and they find it an uncomfortable and unacceptable position in which to be placed (Gatrell et al., 2014).

As a result, it seems that while some fathers continue to 'fall back' into gendered roles (Miller, 2011) others (regardless of their relationship status) are starting to challenge notions that family support at work should be less available to men than to women (Gatrell et al., 2014). Although, arguably, fathers may view with rose coloured spectacles the apparently privileged position afforded to mothers vis a vis flexible working, some men are contesting instances where they consider themselves to be unfairly treated compared with mothers. As a result, while some men may be still constrained by organizational expectations about fathers as primary breadwinners (especially when children are infants) others are reframing personal narratives regarding work, child care, and paternal entitlement to family friendly working (Holter, 2007). Thus, in recent research by Gatrell et al., (2015) fathers in a range of relationship contexts (single, married/co-habiting, extended families) are shown to feel entitled to organize their working lives around children, rather than prioritizing workplace 
needs, due to a combination of both desire and requirement to engage in child care. As one father put it, 'it's the kids that come first with me'.

These findings are mirrored in the recent Scottish Government report 'Fathers in the early years: how do they balance their work and family lives' (Kadar-Satat and Koslowski 2015). This report demonstrates how a proportion of fathers are seeking pro-actively to 'deepen' father-child relationships, many looking to access flexible working in order to support this need (2015:26).

In both Gatrell et al., (2015) and Kadar-Satat and Koslowski’s (2015) studies, instances are shown where men have exhibited determination to access flexible working in order to care for dependent children. Kadar-Satat and Koslowski, for example, report specific examples where fathers are determined not to compromise family time. They quote one father who works flexibly in order to disrupt gender conventions, ensuring that child care is not divided according to:

‘.gender lines. I can take some responsibility for looking after him, which is important, kind of ideologically important on a personal basis' (Kadar-Satat and Koslowski, 2015: 25).

Other men are shown to bench mark their situation against other employers, prioritising their entitlement to engage consistently with child care. For the father quoted below, the chance to access family support initiatives is a motivation to remain with his organization: 
'I'm not a father who doesn't see his children. I've got friends whose employer works them to the bone and they don't get home until after bedtime and they leave early in the morning so they don't get that...it's only weekends and ... they have to compress ...fatherhood ... into 48 hours and less. [But] I am a 7-day-a-week dad, not just a 2-day-a week dad.' (Kadar-Satat and Koslowski, 2015: 26)

The idea that fathers demonstrate a growing sense of entitlement to access family friendly working suggests that organizations may need to rapidly re-think situations where men are effectively excluded from opportunities to work flexibly.

Given the evidence provided by Gatrell et al., (2015) and Kadar-Satat and Koslowski (2015), it is arguable that a sense of entitlement to family support is intensifying among some men. If this is the case, today's fathers might be increasingly prepared to contest a situation where they regard themselves as unfairly excluded from benefits which they feel should be afforded to them. In keeping with the findings of the above two studies, it is reasonable to speculate that some fathers may be prepared to change employers if the perceive better family support to be on offer elsewhere. The sense of men's changing views about entitlement to family support and flexible working opportunities is illustrated in Figure 2. 


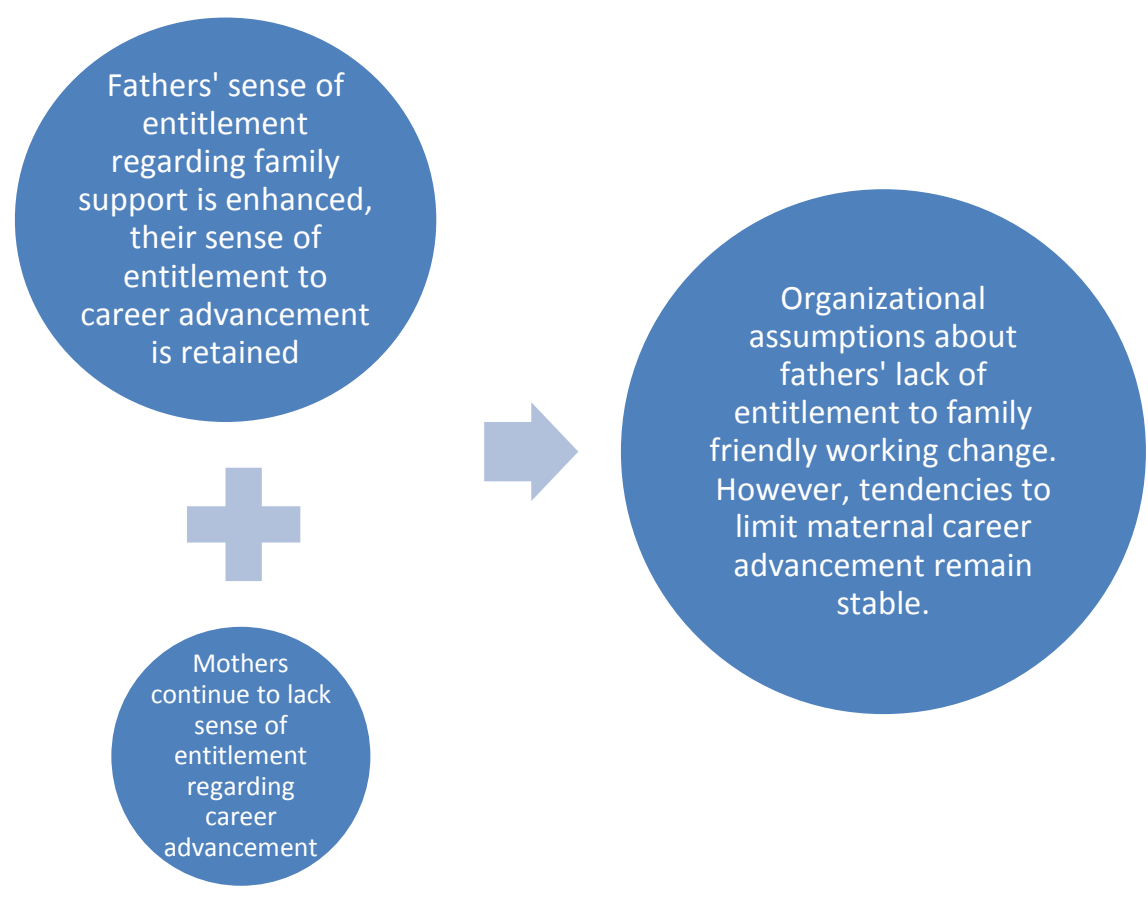

Figure 2: Men’s sense of entitlement to family friendly working increases while women's sense of entitlement to career advancement remains stable

As well as showing men's increased sense of entitlement to family friendly working, Figure 2 also shows how the situation for women may remain stable - and, consequently, problematic.

While women may feel entitled to ask for flexible working in order to meet family needs, they are also known to recognise that such benefits are likely to be accompanied by a downshift in career advancement (Smithson et al., 2004). While this may feel unfair, and a source of resentment, many mothers are prepared to shoulder the cost of career limitation as the price of being able to spend more time with dependent children. While it is perhaps too soon to be certain whether, or how, men's entitlement to career advancement would be affected by enhanced family support, research by Gatrell et al (2014) indicates that fathers would be resistant to any negative impact on their workplace ambitions. If it transpires that contemporary fathers are able to draw upon a paternal sense of entitlement to negotiate their situation regarding family support, but without losing their sense of entitlement to career 
advancement, it will be crucially important to ensure that women do not suffer a double disadvantage. If men feel entitled to access both flexible working and career advancement, while mothers continue to accept the organizational price extracted for balancing child care with employment, there is a danger that gendered inequalities at work will become even more pronounced than at present.

In conclusion, we would like to return to the importance of Lewis's work to the work-life balance field. Her consistent call for work-life balance research to look beyond the narrow focus on heterosexual dual earner couples has enabled the articulation of gendered values and practices in organizations over a twenty year period. It has also helped in breaking down the disciplinary silos between the fields of sociology, organizational psychology and management. This has brought a richness to the field which enables cross disciplinary understandings and facilitates critiques of both research and practice.

Such critiques will be important for a future research agenda which needs to acknowledge the relationships between research, policy and practice (Kossek et al., 2011) and the need to keep sight of the changing needs and priorities of mothers and fathers - observing in particular the requirement for mothers, as well as fathers, to extend their entitlement to both career advancement and work-family initiatives.

\section{References}

Bianchi, S., Milkie, M., Sayer, L. \& Robinson, J. (2000). "Is anyone doing the housework?” Trends in the gender division of household labor, Social Forces, 79, pp. 191-228.

Blair-Loy, M. (2003). Competing devotions: Career and family among women executives, Cambridge, Massachusetts: Harvard University Press. 
Burnett, S.B., Gatrell, C., Cooper, C. \& Sparrow, P. (2010). Fatherhood and flexible working: a contradiction in terms? In Kaiser, S., Ringlstetter, M.J., Eikhof, D.R. \& Pina e Cunha, M. (eds) Creating balance? International perspectives on the work-life integration of professionals (pp. 157-171). New York: Springer.

Brandth, B. \& Kvande, E. (2001). Flexible work and flexible fathers. Work, Employment and Society, 15, 251-267.

Christiansen, S. L. \& Palkowitz, R. (2001). Why the “good provider” role still matters: Providing as a form of paternal involvement, Journal of Family Issues, 22, 84-106.

Collins, G., (2007). Cleaning and the work-life balance, The International Journal of Human Resource Management, 18, 416 - 429.

Collinson, D. \& Collinson, M. (2004), The power of time: leadership, management and gender. In Epstein, CF. \& Kalleberg, A.L. (eds) Fighting for time: Shifting the boundaries of work and social life (pp. 219-46). New York: Russell Sage Foundation.

Coltrane, S., Parke, R. D., \& Adams, M. (2004). Complexity of Father Involvement in LowIncome Mexican American Families*. Family Relations,53(2), 179-189.

Crompton, R. (1997). Women and work in modern Britain. Oxford: Oxford University Press. 
Crouter, A.C., Bumpus, M.F., Head, M.R. \& McHale, S.M. (2001). Implications of overwork and overload for the quality of men's family relationships. Journal of Marriage and Family, 63, 404-416.

Davidson, M.J. \& C.L. Cooper (1992). Shattering the glass ceiling: The woman manager. London: Paul Chapman Publishing.

Delphy, C. \& Leonard, D. (1992). Familiar exploitation: a new analysis of marriage in contemporary western societies. Oxford: Polity Press.

Dermott, E. (2008).Intimate fatherhood: a sociological analysis, Abingdon: Routledge.

Desmarais, S. \& Alksnis, C. (2005). Gender issues. In Barling, J., Kelloway, K. \& Frone, M., (eds), Handbook of work stress (pp. 445-87). Thousand Oaks, California: Sage.

Dienhart, A. (1998). Reshaping fatherhood: The social construction of shared parenting. California: Sage.

Doucet, A. (2006). Do men mother?: Fathering, care, and domestic responsibility. University of Toronto Press.

Eräranta, K. \& Moisander, J. (2011). Psychological regimes of truth and father identity: challenges for work/life integration, Organization Studies, 32, 509-26. 
Estes, S. B. (2004). How are family -responsive workplace arrangements family friendly? Employer accommodations, parenting and children's socio-emotional well-being. The Sociological Quarterly, 45, 637 - 661.

Featherstone, B. (2009). Contemporary fathering: theory, policy and practice, Bristol: Policy Press.

Fleetwood, S. (2007). Why work-life balance now? International Journal of Human Resource Management, 18, 351 - 360.

Ford, J. \& Collinson, D. (2011). In search of the perfect manager? Work-life balance and managerial work, Work, Employment \& Society, 25, 257-73.

Gatrell, C. (2005). Hard labour: The sociology of parenthood, Maidenhead: Open University Press.

Gatrell, C. (2007). Whose child is it anyway? The negotiation of paternal entitlements within marriage, The Sociological Review, 55, 353 - 373.

Gatrell, C.J, Burnett, S, Cooper, C.L. \& Sparrow, P. (2014). Parents, perceptions and belonging: Exploring flexible working among UK fathers and mothers. British Journal of Management, 25, 473-487. 
Gatrell, C. J., Burnett, S. B., Cooper, C. L., \& Sparrow, P. (2015). The price of love: the prioritisation of childcare and income earning among UK fathers. Families, Relationships and Societies, 14, 225-238

Gershuny, J., Godwin, M. \& Jones, S. (1994). The domestic labour revolution: A process of lagged adaptation? In Anderson, M., Bechhofer, F. \& Gershuny, J (eds) The social and political economy of the household. Oxford: Oxford University Press.

Gershuny, J. (1997). Sexual divisions and the distribution of work in the household. In Dench, G., (ed) Rewriting the Sexual Contract (pp.141-152). London, Institute of Community Studies.

Greenhaus, J. \& Beutell, N. (1985). Source of conflict between work and family roles, Academy of Management Review, 10, 76-88.

Greenhaus, J H., Parasuraman, S., Granrose, C.S., Rabinowitz, S. \& Beutell, N.J. (1989). Sources of work-family conflict among two-career couples, Journal of Vocational Behavior, 34, 133-153.

Halford, S. (2006). Collapsing the boundaries? Fatherhood, organization and home-working. Gender, Work and Organization, 13, 383-402.

Hochschild, A. (1997). The time bind: When work becomes home and home becomes work. New York: Henry Holt.

Holter, O. (2007). Men’s work and family reconciliation in Europe, Men and Masculinities, 9, 425-56. 
Höpfl H and Hornby Atkinson P (2000) The future of women’s careers. In: Collin A and Young R (eds) The Future of Career. Cambridge: Cambridge University Press, pp.130-43.

Kanter, R. (1976). Work and family in America: A critical review and research agenda.

Social Science Frontiers Monograph Series, New York: Russell Sage.

Kadar-Satat, G and Koslowski, A., (2015) Fathers in the early years: How do they balance their work and family life? Family Friendly Working Scotland, http://www.gov.scot/Resource/0047/00477645.pdf(downloaded 3 December 2015)

Kossek, E., Baltes, B.B. \& Mathews, A. (2011). Innovative ideas on how work-family research can have more impact. Industrial and Organizational Psychology, 4, 1-7.

Kvande, E. (2005). Embodying male workers as fathers in a flexible working life. In Morgan, D., Brandth, B. \& Kvande, E. (eds) Gender, bodies and work. Aldershot: Ashgate.

Lewis, S. (1997). 'Family friendly’ employment policies: a route to changing organizational culture or playing about at the margins? Gender, Work \& Organization, 4, 13-23.

Lewis, S. \& Cooper, C.L. (1999). The work-family agenda in changing contexts, Journal of Occupational Health Psychology, 4, 382-93.

Lewis, S. \& Cooper, C. (2005). Work-life integration: Case studies of organisational change. Chichester: John Wiley. 
Lewis, S., Gambles, R. \& Rapoport, R. (2007). The constraints of a work-life balance approach: an international perspective. The International Journal of Human Resource Management, 18, 360-74.

Maushart, S. (2002). Wifework: What marriage really means for women. London: Bloomsbury Press.

Miller, T. (2010). Making sense of fatherhood: gender and caring work, Cambridge:

Cambridge University Press.

Miller, T. (2011). Falling back into gender? Men’s narratives and practices around first-time fatherhood, Sociology, 45, 1094-1109.

Moss, P (ed). (2014). 10th International Review of Leave Policies and Related Research 2014. University of London, Institute of Education.

Neale, B. \& Smart, C. (2002). Caring, earning and changing, Parenthood and employment after divorce. In Carling, A., Duncan, S. \& Edwards, R. Analysing families, morality and rationality in policy and practice (pp. 183-199). London and New York: Routledge.

Oakley, A. (1981). From here to maternity: Becoming a mother. London: Penguin Books. 
Özbilgin, M.F, Beauregard, T.A., Tatli, A. \& Bell, M.P. (2011). Work-life, diversity and intersectionality: a critical review and research agenda. International Journal of Management Reviews, 13, 177-98.

Padavic, I. \& Reskin, B. (2002). Women and men at work. California: Sage.

Parasuraman, S., Greenhaus, J. H., Rabinowitz, S., Bedeian, A. G., \& Mossholder, K. W. (1989). Work and family variables as mediators of the relationship. Academy of Management Journal, 32, 185-202.

Pleck, J. H. (1977). The work-family role system. Social Problems, 24, 417-427.

Philip, G. (2013). Relationality and moral reasoning in accounts of fathering after separation or divorce: care, gender and working at 'fairness', Families, Relationships and Societies, 2, 409-24.

Philip, G. (2014) Fathering after separation or divorce: navigating domestic, public and moral spaces, Families, Relationships and Societies, 3, 219-33.

Rapoport, R. \& Rapoport, R.N. (1965). Work and family in contemporary society, American Sociological Review, 30, 381 -94.

Ribbens, J. (1994). Mothers and their children: A feminist sociology of childrearing. London: Sage. 
Rich, A. (1977). Of woman born: Motherhood as experience and institution, London: Virago.

Shirani, F. (2015). 'I’m bringing back a dead art': continuity and change in the lives of young fathers. Families, Relationships and Societies, 4, 253-266.

Smart, C. \& Neale, B. (1999). Family fragments? Cambridge: Polity Press.

Smart, C, Neale, B. \& Wade, A. (2001). The changing experience of childhood: Families and divorce, Cambridge: Polity Press.

Smithson, J., Lewis, S., Cooper, C., \& Dyer, J. (2004). Flexible working and the gender pay gap in the accountancy profession. Work, Employment \& Society, 18, 115-135.

Smithson, J. \& Stokoe, E. H. (2005). Discourses of work-life balance: negotiating 'genderblind' terms in organizations, Gender, Work \& Organization, 12, 147-68.

Swan, J. \& Cooper, C.L. (2005). Time, health and the family: What working families want. London: A Working Families Publication.

Thompson, C.A., Beauvais, L. \& Lyness, K.S. (1999). When work-family benefits are not enough: The influence of work-family culture on benefit utilization, organizational attachment, and work-family conflict. Journal of Vocational Behavior, 54, 392-415. 
Tomlinson, J. (2007). Employment regulation, welfare and gender regimes: a comparative analysis of women's working-time patterns and work-life balance in the UK and the US. The International Journal of Human Resource Management, 18, 401-417.

Tracy S.J. \& Rivera K.D. (2010). Endorsing equity and applauding stay-at-home moms: how male voices on work-life reveal aversive sexism and flickers of transformation. Management Communication Quarterly, 24, 3-43.

Working Families (2011). Working and fathers: combining family life and work. http://www.workingfamilies.org.uk/publications/working-and-fathers-combining-family-lifeand-work (downloaded November 18 2015).

Working Families (2015). Additional paternity leave and additional statutory paternity pay http://www.workingfamilies.org.uk/articles/additional-paternity-leave-and-additionalstatutory-paternity-pay/ (downloaded November 18 2015).

Worrall, L. \& Cooper, C.L. (1999). Working patterns and working hours: their impact on UK managers. Leadership and Organization Development Journal, 20, 6-10. 